\title{
Diversity of ectoparasites and endoparasites infecting Brachyplatystoma vaillantii (Siluriformes: Pimelodidae), a large migratory catfish from the Amazon
}

\author{
Ivanildo Amanajás BRITO-JUNIOR ${ }^{1}$, Marcos TAVARES-DIAS ${ }^{2 *} \odot$ \\ 'Faculdade de Macapá (FAMA), Macapá, AP, Brazil \\ ²Embrapa Amapá, Macapá, AP, Brazil \\ *Corresponding author: marcos.tavares@embrapa.br; (1) https://orcid.org/0000-0002-8376-1846
}

\begin{abstract}
Brachyplatystoma vaillantii is a large migratory catfish widely distributed in the Amazon basin, but its parasitic fauna is still poorly known. As it is an important fishery resource in the region of the Amazonas River estuary, the aim of this study was to investigate the parasite community in B. vaillantii from a tributary of the Amazonas River estuary system, in Brazil. We examined 31 juvenile fish, of which $80.6 \%$ were parasitized, and a total of 586 parasites were collected. We identified Dermidospermus brachyplastystimae and Dermidospermus araguiensis (Monogenea), Genarchella genarchella (Digenea), Harriscolex piramutab (Cestoda), Pseudoterranova sp. (Nematoda), Ergasilus xinguensis (Crustacea) and mites (Acarina). The dominance was of Pseudoterranova sp. larvae. The parasite community of B. vaillantii was composed of low values of species richness $(2.0$ $\pm 1.4)$, evenness $(0.18 \pm 0.21)$ and diversity $(0.32 \pm 0.37)$, with predominance of ectoparasite species with low prevalence, low abundance and overdispersion. Host body weight was the main correlate of parasite diversity and abundance, and a diet rich in crustaceans and other invertebrates may be important in structuring the parasite community of $B$. vaillantii. This is the first report of Dermidospermus brachyplastystimae and D. araguiensis, Pseudoterranova sp. and G. genarchella for B. vaillantii.
\end{abstract}

KEYWORDS: fish, parasites, Laulao catfish, helminths, crustaceans, mites

\section{Diversidade de ectoparasitos e endoparasitos infestando Brachyplatystoma vaillantii (Siluriformes: Pimelodidae), um grande bagre migratório da Amazônia}

\section{RESUMO}

Brachyplatystoma vaillantii é um grande bagre migratório amplamente distribuído na bacia Amazônica, mas sua fauna parasitária ainda é pouco conhecida. Por ser um importante recurso pesqueiro na região do estuário do Rio Amazonas, o objetivo deste estudo foi investigar a comunidade parasitária em $B$. vaillantii de um afluente do sistema estuarino do Rio Amazonas, no Brasil. Foram examinados 31 peixes juvenis, dos quais 80,6\% estavam parasitados, e um total de 586 parasitos foram coletados. Foram identificados Dermidospermus brachyplastystimae e Dermidospermus araguiensis (Monogenea), Genarchella genarchella (Digenea), Harriscolex piramutab (Cestoda), Pseudoterranova sp. (Nematoda), Ergasilus xinguensis (Crustacea) e ácaros (Acarina). A dominância foi de larvas de Pseudoterranova sp. A comunidade parasitária de B. vaillantii foi composta por baixos valores de riqueza de espécies $(2,0 \pm 1,4)$, equitabilidade $(0,18 \pm 0,21)$ e diversidade $(0,32 \pm 0,37)$, com predominância de espécies de ectoparasitos com baixa prevalência, baixa abundância e dispersão agregada. $\mathrm{O}$ peso corporal do hospedeiro foi o principal correlato da diversidade e abundância de parasitos, e uma dieta rica em crustáceos e outros invertebrados podem ser importante na estruturação da comunidade parasitária de B. vaillantii. Este foi o primeiro relato de D. brachyplastystimae, D. araguiensis, Pseudoterranova sp. e G. genarchella para B. vaillantii.

PALAVRAS-CHAVE: ácaros, crustáceos, helmintos, parasitos, peixe, piramutaba

\section{INTRODUCTION}

Brachyplatystoma vaillantii Valenciennes, 1840 (Siluriformes), is a Pimelodidae fish native to northern South America, known as piramutaba or laulao catfish, which is an important fishing resource in the region of the Amazonian estuary. It is one of the large migratory catfishes with wide distribution in the Amazonas and Orinoco river basins, as well as river basins from the Guianas (Soares et al. 2011; Froese and Pauly 2019). This benthic species inhabits the channel of the Amazon River and its major tributaries. The young consume crustaceans (mainly prawns) and insects, and the adults are piscivorous 
and can reach up to $1.5 \mathrm{~m}$ in total length and weigh $10 \mathrm{~kg}$. It performs annual migrations between its feeding grounds in the Amazonas River estuary and its reproduction grounds near the Brazil-Peru-Colombia border region. Females reach sexual maturity with $42 \mathrm{~cm}$ of length and, after spawning, larvae and juveniles drift until reaching the Amazonas estuary, which is the main growth environment for this fish. Brachyplatystoma vaillantii is heavily exploited by the artisanal and industrial fishery at the mouth of the Amazonas River (Soares et al. 2011; Barthem et al. 2015; Jimenez et al. 2017; Froese and Pauly 2019).

Despite the wide distribution of $B$. vaillantii in the Amazonas basin, there are only a few studies on its parasites, mostly on taxonomy. Studies on community aspects of its parasite fauna, however, are lacking, despite their interest related to the complexity of the life history and distribution of this fish. Studies on the diversity of fish parasites are important due to the role of parasites as indicators of environmental quality and ecosystem health, which are useful tools in the conservation and maintenance of local biodiversity (Cardoso et al. 2017; Oliveira et al. 2017; Leite et al. 2018). Parasites can change the composition and structure of the host community due to alterations in the environment that influence the functioning and stability of the ecosystems (Vasconcelos and Tavares-Dias 2016; Santos and Tavares-Dias 2017; Cardoso et al. 2017). Changes caused by parasites can lead to negative impacts on fishery production due to losses in quality and quantity of fish, reduction in body weight and injuries, which can result in the disposal of part of the catch (Cardoso et al. 2017) and reduce the potential economic benefits that fisheries may generate.

Reported parasites for B. vaillantii from the Brazilian Amazon are the cestodes Pterobothrium crassicole Diesing, 1850; Goezeella siluri Fuhrmann, 1916; Amazotaenia yvettae Chambrier, 2001; Amphoteromorphus ninoi Carfora, Chambrier \& Vaucher, 2003; Harriscolex piramutab (Woodland, 1933) Chambrier, Kuchta \& Scholz, 2015; Nomimoscolex suspectus Zehnder, Chambrier, Vaucher \& Mariaux, 2000, and the coccidian Calyptospora sp. (Rego 1984; Silva et al. 2012; Alves et al. 2017a,b). In the Peruvian Amazon, B. vaillantii was found to be infected with the cestodes Chambriella sp. and H. piramutab, and monogeneans of the genus Demidospermus (Mendoza-Palmero et al. 2015; Chambrier et al. 2015). In Venezuela, the infection of $B$. vaillantii by G. siluri and Harriscolex kaparari (Woodland, 1935) Rego, 1987 (Alves et al. 2017a,b) was reported. To date, there has been no study reporting quantitative and qualitative descriptors of the parasite community in a wild B. vaillantii population. Therefore, the aim of this study was to describe the communities of ecto and endoparasites of $B$. vaillantii from a tributary of the Amazonas River estuary system, in the northern Brazilian, state of Amapá Region.

\section{MATERIAL AND METHODS}

\section{Study area and fish collection}

Between November and December 2017, 31 specimens of $B$. vaillantii juveniles $(152.5 \pm 76.7 \mathrm{~g}$ and $21.5 \pm 3.7 \mathrm{~cm}$ total length) were collected in the Igarapé Fortaleza River basin, in the municipality of Macapá, Amapá state, northern Brazil (Figure 1) for parasitological analyses. The fish were captured using gill nets with mesh sizes from 30 to $70 \mathrm{~mm}$. This study was approved by the ethics committee in the use of animal of Embrapa Amapá (Protocol No 004/2016 CEUA/Embrapa Amapá) and authorized by SISBIO license \# 23276-1 issued by Instituto Brasileiro do Meio Ambiente e dos Recursos Naturais Renováveis (IBAMA).

The Igarapé Fortaleza hydrographic basin (Figure 1) has an area of $195 \mathrm{~km}^{2}$ which drains from the north into the estuary system of the Amazon River (Takiyama et al. 2004, Silva et al. 2009). It is a river system with extensive floodplains and is influenced by high rainfall and the daily tides of the Amazon River. During the rainy season, the waters are rich in nutrients due to the fast decomposition of plant and animal remains and the layer of forest humus from the inundated floodplain forests, leading to the increase of vegetation and invertebrate biomass (insects, crustaceans and mollusks), which are used as food by fish (Takiyama et al. 2004). The margins of the floodplain are vegetated by species of diverse vegetation species, along with macrophytes of Cabombaceae, Lentibulariaceae, Salviniaceae and Cyperaceae (Thomaz et al. 2004). The area of the basin is under pressure from urban land occupation and buffalo ranching, associated with deforestation, burning of vegetation and solid waste dumping. The $\mathrm{pH}$ of the water varies from 5.5 to 7.5 and the oxygen levels from 2.5 to $6.0 \mathrm{mg} / \mathrm{L}$, depending on the area of the basin and the season (Takiyama et al. 2004).

\section{Collection and analysis of parasites}

The collected fish were weighed (g) and measured in total length $(\mathrm{cm})$ and necropsied for parasitological analysis. We examined the mouth, opercula, gills, viscera and gastrointestinal tract of each fish. Gills were removed for collection of ectoparasites, and the gastrointestinal tract and viscera were removed and examined for endoparasites under a stereomicroscope (Zeiss). The collection, fixation, preservation, counting and staining of the parasites for identification followed Eiras et al. (2006). The identification of parasites was according to Moravec (1998) and Thatcher (2006). Voucher specimens were deposited at Instituto de Pesquisas Cientificas e Tecnológicas do Estado do Amapá (IEPA), Macapá, Amapá, Brazil, in the Scientific Collection Curation Office for the Fauna of Amapá, under accession number IEPA 160-165P.

We calculated the ecological indices (prevalence, mean intensity and mean abundance) host) following Bush et al. (1997). We used the Diversity software (Pisces Conservation 


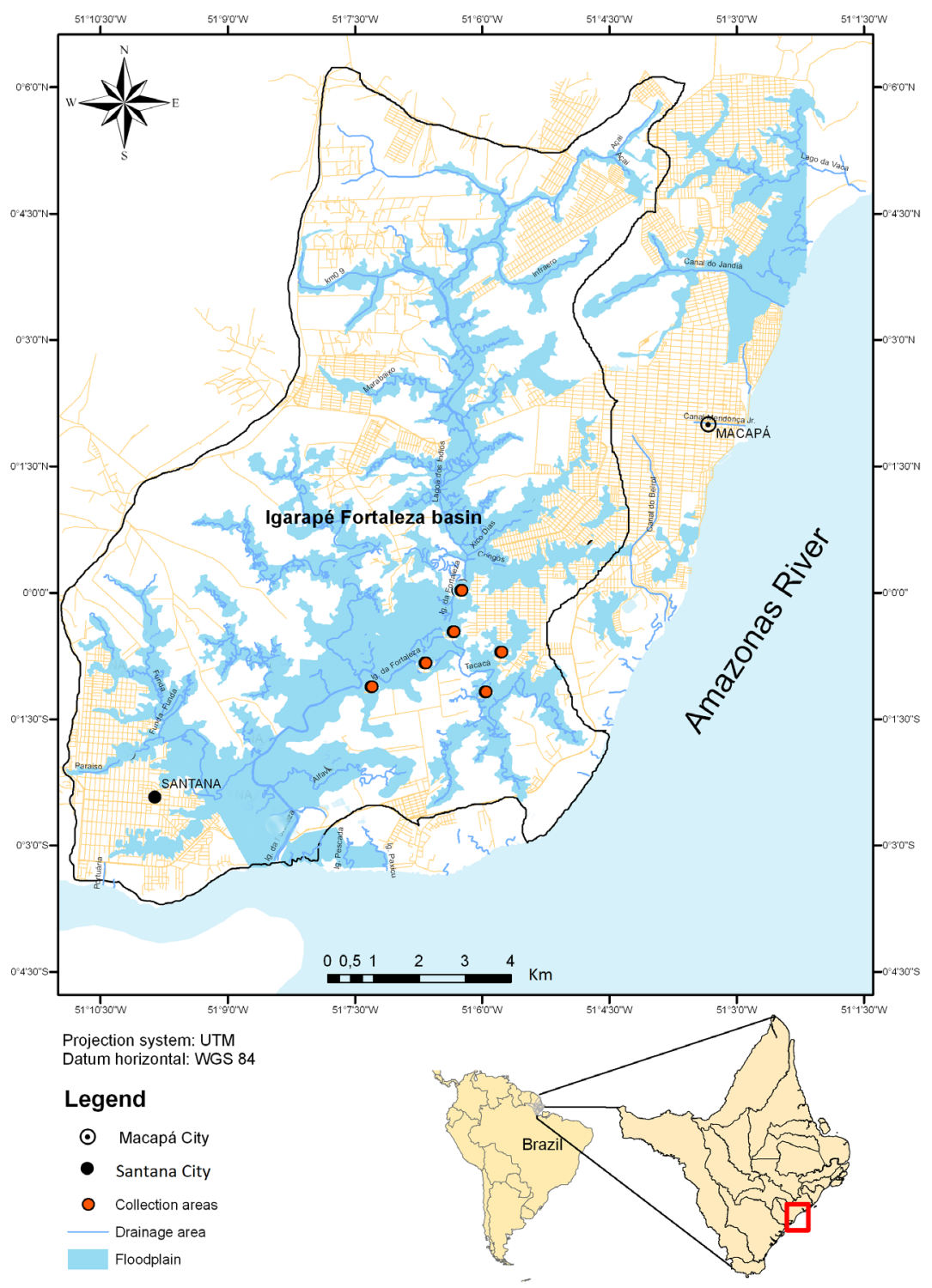

Figure 1. Collection sites of Brachyplatystoma vaillanti in the Igarapé Fortaleza river basin, a tributary of the Amazonas River estuary system, in Brazil. This figure is in color in the electronic version.

Ltd., UK) to calculate the following descriptors for the parasite component community: species richness of parasites, the Brillouin diversity index $(H B)$, evenness $(E)$ in association with the diversity index, and the dominance frequency (percentage of the infracommunities in which a parasite species is numerically dominant) (Rohde et al. 1995; Magurran 2004). In order to detect the distribution pattern of the parasite infracommunities (Rózsa et al. 2000), the index of dispersion (ID) and the Poulin discrepancy index (D) were calculated for species with prevalence $>10 \%$ using the Quantitative Parasitology 3.0 software. The ID significance for each infracommunity was tested using the $d$-statistics (Ludwig and Reynolds 1988). The correlation of parasite abundance with the length and weight of hosts, as well as with species richness and the Brillouin diversity index was analyzed using the Spearman correlation coefficient (Zar 2010).

\section{RESULTS}

Overall, $80.6 \%$ of the 31 fish were parasitized. Parasites belonged to two species of Monogenea, one Digenea, one Nematoda, one Cestoda, one Crustacea and one unidentified species of Acarina (Table 1). A total of 586 individual parasites were collected, of which $71.4 \%$ were ectoparasites, and $28.6 \%$ endoparasites, thus the component community was dominated by ectoparasites, that were characterized by low prevalence, low abundance and overdispersion (Tables 1; Table 2). The monogeneans were identified to genus level (Dermidospermus) by standard stereomicrocopic examination, 
and a partial microscopic examination of the sample revealed the presence of Dermidospermus brachyplastystimae Cepeda \& Luque, 2016 and Dermidospermus araguiensis Cepeda $\&$ Luque. As not all individuals were identified to species level, we used the pooled sample of Dermidospermus sp. for analysis and parameter calculation. The dominant species was Pseudoterranova sp. (Nematoda) and all individuals were larvae (Table 1). The parasites presented an aggregate dispersion, except for Ergasilus xinguensis Taborda, Paschoal \& Luque, 2016 (Crustacea), which showed random dispersion (Table 2). There was a predominance of hosts with one and three species of parasites (Figure 2).

The species richness of parasites per host was $2.0 \pm 1.4$ (05), the Brillouin diversity index was $0.32 \pm 0.37(0-1.21)$ and the evenness was $0.18 \pm 0.21(0-0.68)$. The Brillouin index showed no correlation with the length of hosts $(r s=0.31, \mathrm{p}=$ $0.09, n=31$ ), while species richness of parasites showed a weak positive correlation with host length $(r s=0.38, \mathrm{p}=0.03, \mathrm{n}=$
31). Host weight was positively correlated with the Brillouin diversity ( $r s=0.43, \mathrm{p}=0.01, \mathrm{n}=31)$ and the species richness of parasites ( $r s=0.50, \mathrm{p}=0.004, \mathrm{n}=31)$.

The abundance of Dermidospermus spp. was positively correlated with the length of hosts $(r s=0.43, \mathrm{p}=0.02, \mathrm{n}=$ 31). There was no correlation between the length of hosts and the abundance of the crustacean E. xinguensis ( $r s=0.27, \mathrm{p}=$ $0.14, \mathrm{n}=31$ ), the digenean Genarchella genarchella Travassos, Artigas \& Pereira, $1928(r s=0.20, \mathrm{p}=0.27, \mathrm{n}=31)$ and the nematode Pseudoterranova sp. $(r s=-0.18, \mathrm{p}=0.32, \mathrm{n}=$ 31). The abundance of Dermidospermus spp. also presented a positive correlation $(r s=0.59, \mathrm{p}=0.0005, \mathrm{n}=31)$ with the weight of hosts, while the abundance of E. xinguensis was weakly positively correlated with host weight $(r s=0.36, \mathrm{p}=$ $0.04, \mathrm{n}=31)$. The abundance of $G$. genarchella $(r s=0.18, \mathrm{p}=$ $0.31, \mathrm{n}=31)$ and of Pseudoterranova sp. $(r s=-0.19, \mathrm{p}=0.31$, $\mathrm{n}=31)$ presented no correlation with the length of hosts.

Table 1. Parasites of Brachyplatystoma vaillantii $(n=31)$ from the Igarapé Fortaleza basin, on the northern margin of the Amazonas River estuary system, in Brazil. $\mathrm{P}$ = prevalence; $\mathrm{MI}=$ mean intensity; $\mathrm{MA}=$ mean abundance; $\mathrm{FD}=$ frequency of dominance; $\mathrm{TNP}=$ total number of parasites. Values for $\mathrm{MA}$ are the mean followed by the standard deviation.

\begin{tabular}{|c|c|c|c|c|c|c|c|}
\hline Parasites & $P(\%)$ & $\mathrm{Ml}$ & MA & Range & TNP & FD (\%) & Infection site \\
\hline \multicolumn{8}{|l|}{ Monogenea } \\
\hline Dermidospermus spp.* & 48.4 & 4.8 & $2.3 \pm 3.4$ & $1-11$ & 72 & 12.0 & Gills \\
\hline \multicolumn{8}{|l|}{ Digenea } \\
\hline Genarchella genarchella (metacercariae) & 16.1 & 3.2 & $0.5 \pm 1.6$ & $1-8$ & 16 & 3.0 & Gills \\
\hline \multicolumn{8}{|l|}{ Nematoda } \\
\hline Pseudoterranova sp. (larvae) & 54.8 & 27.2 & $14.9 \pm 24.0$ & $1-78$ & 462 & 79.0 & Intestine \\
\hline \multicolumn{8}{|l|}{ Cestoda } \\
\hline Harriscolex piramutab (larvae) & 9.7 & 2.3 & $0.2 \pm 0.9$ & $1-78$ & 7 & 1.0 & Intestine \\
\hline \multicolumn{8}{|l|}{ Crustacea } \\
\hline Ergasilus xinguensis & 38.7 & 2.3 & $0.8 \pm 1.5$ & $1-7$ & 27 & 5.0 & Gills \\
\hline \multicolumn{8}{|l|}{ Acarina } \\
\hline Acarina gen. sp. & 3.2 & 1.0 & $0.03 \pm 0.18$ & $1-1$ & 1 & 0.2 & Gills \\
\hline
\end{tabular}

* The sample includes Dermidospermus brachyplastystimae and D. araquiensis

Table 2. Dispersion index (ID), $d$-statistics and discrepancy index (D) for the parasites in Brachyplatystoma vaillantii $(n=31)$ from the Igarapé Fortaleza basin, on the northern margin of the Amazonas River estuary system, in Brazil.

\begin{tabular}{lcccc}
\hline Species & ID & d & D & Dispersion type \\
\hline Dermidospermus spp.* & 2.065 & 3.32 & 0.631 & Aggregated \\
\hline Genarchella genarchella** & 1.881 & 2.81 & 0.847 & Aggregated \\
\hline Pseudoterranova sp. & 2.425 & 4.25 & 0.601 & Aggregated \\
\hline Ergasilus xinguensis & 1.416 & 1.41 & 0.676 & Random \\
\hline
\end{tabular}

* The sample includes Dermidospermus brachyplastystimae and D. araguiensis ** metacercariae

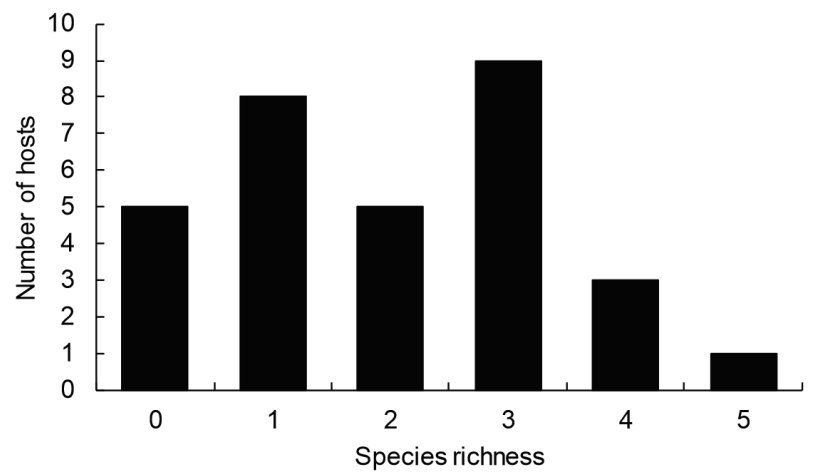

Figure 2. Species richness of parasites found in 31 individuals of Brachyplatystoma vaillanti (Pimelodidae) in the Igarapé Fortaleza river basin, a tributary of the Amazonas River estuary system, in Brazil. 


\section{DISCUSSION}

In wild populations of fish, species richness of parasites is considered a reflection of the number of host species present in the environment and the local capacity for transmission and infection of intermediate and definitive hosts (Bellay et al. 2013; Santos and Tavares-Dias 2017; Oliveira et al. 2017; Cardoso et al. 2017). Abundance and diversity of invertebrates that act as intermediate hosts to parasites are key components in the composition of endoparasite communities in wild fish populations (Luque et al. 2013; Bellay et al. 2013; Cardoso et al. 2017; Santos and Tavares-Dias 2017; Oliveira et al. 2017). The B. vaillantii of Igarapé Fortaleza examined in this study had low parasite species richness and diversity for ecto and endoparasites, probably due to the low availability of invertebrates that act as intermediate hosts for the endoparasites. All diversity indices and evenness had low values, indicating an uneven distribution of parasite species diversity across the host sample and specific species dominance in abundance (Pseudoterranova sp. in our sample). This is a common pattern in communities of fish parasites with a relatively low species diversity, but with low abundance (Cardoso et al. 2017; Oliveira et al. 2017; Santos and TavaresDias 2017; Leite et al. 2018).

The aggregated distribution pattern of parasites observed in B. vaillantii followed the same pattern reported for other freshwater host species (Guidelli et al. 2003; Vasconcelos and Tavares-Dias 2016; Cardoso et al. 2017; Oliveira et al. 2017; Santos and Tavares-Dias 2017; Leite et al. 2018). This pattern is related to random environmental variables, such as heterogeneity in host susceptibility to infections, direct reproduction of the parasite within the host and heterogeneity in the host ability to eliminate parasites by immunological response (Guidelli et al. 2003; Santos and Tavares-Dias 2017; Oliveira et al. 2017; Leite et al. 2018). The random distribution of E. xinguensis in B. vaillantii has also been reported for the congeneric Ergasilus turucuyus Malta \& Varella, 1996 in Acestrorhynchus falcirostris Cuvier, 1819 and for Excorallana berbicensis Boone, 1918 in Serrasalmus gibbus Castelnau, 1855 (Vasconcelos and Tavares-Dias 2016). The random dispersion pattern may be related to a reduced opportunity to colonize this host in the environment (Guidelli et al. 2003; Vasconcelos and Tavares-Dias 2016).

The parasite fauna of $B$. vaillantii consisted mainly of ectoparasites, particularly monogeneans. The lentic environment inhabited by the examined fishes favors dispersal and reproduction of ectoparasites with free-living stages during some phases of its direct life cycle (Santos and Tavares-Dias 2017; Leite et al. 2018). Monogeneans are helminths with a high host specificity when compared to other groups of helminths, occurring only on one host, or a few hosts that are phylogenetically very closely related. Hence, the structuring of their communities is related to both ecological and historical constraints (Braga et al. 2014; Santos and Tavares-Dias 2017). Dermidospermus brachyplastystimae and D. araguiensis, both parasites of Brachyplatystoma filamentosum Lichtenstein, 1819 (Cepeda and Luque 2010) were also found in gills of $B$. vaillantii. This is the first report of $D$. brachyplastystimae and $D$. araguiensis for $B$. vaillantii.

Young individuals of B. vaillantii, wich composed our sample, consume crustaceans and insects (Soares et al. 2011; Barthem et al. 2015; Jimenez et al. 2017; Froese and Pauly 2019), the environment from Igarapé Fortaleza basin with diversity of several invertebrate species (Takiyama et al. 2004; Thomaz et al. 2004) play an important role by providing feeding grounds. At the same time, these factors increase the possibilities that this host population will acquire endoparasites, as G. genarchella, Harriscolex piramutab (Woodland, 1933) Chambrier, Kuchta \& Scholz, 2015 and Pseudoterranova sp. Digeneans were found for the first time parasitizing the gills of $B$. vaillantii in this study. Digeneans are parasites with complex life cycle, generally involving two or three hosts (Martorelli 1989; Poulin and Cribb 2002; Cardoso et al. 2017). Genarchella genarchella normally has a snail as intermediate host and a fish as definitive host (Martorelli 1989; Poulin and Cribb 2002). The level of infection by metacercariae of $G$. genarchella in the gills of $B$. vaillantii was low when compared to Triportheus rotundatus Jardine, 1841 (Santos and Tavares-Dias 2017), which seem be a paratenic host for this species of digenean.

This is the first report of Pseudoterranova sp. parasitizing $B$. vaillantii. This nematode, which can be a serious threat to human health, had a higher prevalence in $B$. vaillantii than that reported in B. filamentosum from the state of Pará, Brazil (Rodrigues et al. 2015). Pseudoterranova are nematodes that infect different marine and freshwater fish species (McClelland 2002; Hernández-Orts et al. 2013; Rodrigues et al. 2015). Marine Pseudoterranova species have invertebrates (e.g., polychaetes, decapods, copepods, mysids, isopods, etc.) as primary hosts, while fish species are secondary hosts and mammals are definitive hosts (McClelland 2002; HernándezOrts et al. 2013). The life cycle of these endoparasites in freshwater fish is yet unknown but considering what is known of their life cycle in marine environments, the prevalence of Pseudoterranova sp. in B. vaillantii may be related to the benthonic habit of this fish, and the fact that crustaceans, mainly prawns, and insects (Soares et al. 2011; Barthem et al. 2015; Froese and Pauly 2019) are part of its juvenile diet.

South American catfishes, of the order Siluriformes, are definitive hosts of a vast diversity of Proteocephalidae Cestoda species (Alves et al. 2017a,b). Hence, Cestoda is the endohelminth taxon most known for infecting $B$. vaillantii (Rego 1984; Alves et al. 2017a,b). The prevalence of $H$. piramutab in $B$. vaillantii was lower than that reported by Chambrier et al. (2015) for this same host from the Peruvian 
Amazon, and the species also occurred in low mean abundance and intensity in our sample. Our study expands the occurrence of $H$. piramutab to the eastern Amazon.

Ergasilidae is one of the largest families of Cyclopoida, and most species are found on freshwater fish (Tavares-Dias et al. 2015). Only adult females of ergasilids are parasites on gills, fins, the interior nasal fossae, or embedded in host tissues or in the urinary bladder of teleost fish species, and rarely on the gills of elasmobranchs and bivalve mollusks (Taborda et al. 2016). Ergasilus xinguensis was described initially on the cichlids Geophagus argyrostictus Kullander, 1991 and Geophagus altifrons Heckel, 1840 from the western Amazon (Taborda et al. 2016). Its record, albeit at low infection levels, in gills of $B$. vaillantii, indicates that this crustacean ectoparasite has no host specificity.

Mites (Acarina) are usually found on the gills, integument and digestive tract of fish (Olmeda et al. 2011; Lizama et al. 2013). The habitat and behavior of fish do not contribute to mite infestation, and some authors consider mites to be unusual parasites of fish, whereas for others, mites are not fish parasites at all (Olmeda et al. 2011; Lizama et al. 2013). Under certain environmental conditions, however, mites may proliferate and colonize weak or stressed fish causing serious damage. Several genera of mites have been isolated from fish species in Europe, Australia, and North America, in some cases associated with high host mortality (Olmeda et al. 2011; Lizama et al. 2013).

Species richness of parasites and the abundance of Dermidospermus spp. in the gills increased with fish weight and length in our study, in agreement with the general pattern described for parasites in fish (Cardoso et al. 2017; Oliveira et al. 2017; Santos and Tavares-Dias 2017). In wild fish populations, body size is correlated with age, which has been considered a determinant of parasite abundance and species richness in fish, explaining in part the variation of parasitic infracommunities (Poulin 2001; Poulin 2004; Cardoso et al. 2017; Oliveira et al. 2017; Santos and Tavares-Dias 2017). Larger fish provide parasites with more diverse niches and larger colonization areas, allowing larger hosts to harbor a higher species richness and load of parasites (Poulin 2001; Poulin 2004; Oliveira et al. 2017), mainly ectoparasites such as monogeneans, as observed in this study.

\section{CONCLUSIONS}

This was the first study on parasite communities in B. vaillantii and revealed a low species richness and diversity of parasites in juvenile fish in a northern tributary of the Amazonas River estuary system. The parasite component community consisted predominantly of ectoparasite species with low prevalence, low abundance and overdispersion distribution. Species richness and diversity of parasites was more strongly correlated to host weight than to host length. Only the abundance of Dermidospermus spp. was strongly correlated with fish size. Our findings increase the knowledge on the parasite diversity in the Amazon system.

\section{ACKNOWLEDGMENTS}

The authors thank the Conselho Nacional de Desenvolvimento Científico e Tecnológico (CNPq) for the productivity research grant awarded to M. Tavares-Dias (\# 303013/2015-0). The authors also would like to thank Dr. Philippe Bisaggio Pereira of the Laboratory of Animal Parasitology at Universidade Federal de Mato Grosso do Sul (UFMS) for the identification of nematodes.

\section{REFERENCES}

Alves, P.V.; Chambrier, A.; Luque, J.L.; Scholz, T. 2017a. Annotated checklist of fish cestodes from South America. ZooKeys, 650: 1-205.

Alves, P.V.; Chambrier, A.; Luque, J.L.; Scholz, T. 2017b. Reappraisal of Goezeella Fuhrmann, 1916 (Cestoda: Proteocephalidae), parasites of Neotropical catfishes (Siluriformes), with description of a new species from Pimelodella cristata (Heptapteridae). Revue suisse de Zoologie, 124: 335-350.

Barthem, R.B.; Melllo-Filho, A.; Assunçáo, W.; Gomes, P.F.; Barbosa, C.A.C. 2015. Estrutura de tamanho e distribuição espacial da piramutaba (Brachyplatystoma vaillantii) na foz amazônica: implicaçóes para o manejo da pesca. Boletim do Instituto de Pesca, 41: 249-260.

Bellay, S.; Oliveira, E.F.; Almeida-Neto, M.; Lima-Junior, D.P.; Takemoto, R.M.; Luque, J.L. 2013. Developmental stage of parasites influences the structure of fish-parasite networks. PLoS ONE, 8: e75710.

Braga, M.P.; Araújo, S.B.L., Boeger, W.A. 2014. Patterns of interaction between Neotropical freshwater fishes and their gill Monogenoidea (Platyhelminthes). Parasitology Research, 113: 481-490.

Bush, A.O.; Lafferty, K.D.; Lotz, J.M.; Shostak, W. 1997. Parasitology meets ecology on its own terms: Margolis et al. revisited. Journal of Parasitology, 83: 575-583.

Cardoso, A.C.F.; Oliveira, M.S.B.; Neves, L.R.; Tavares-Dias, M. 2017. Metazoan fauna parasitizing Peckoltia braueri and Pterygoplichthys pardalis (Loricariidae) catfishes from the northeastern Brazilian Amazon. Acta Amazonica, 47: 147-154.

Chambrier, A.; Waeschenbach, A.; Fisseha, M.; Scholz, T.; Mariaux, J. 2015. A large 28S rDNA-based phylogeny confirms the limitations of established morphological characters for classification of proteocephalidean tapeworms (Platyhelminthes, Cestoda). ZooKeys 500: 25-59. 10.3897/zookeys.500.9360.

Eiras, J.C.; Takemoto, R.M.; Pavanelli, G.C. 2006. Métodos de Estudos e Técnicas Laboratoriais em Parasitologia de Peixes. Eduem, Maringá, 199p.

Froese, R.; Pauly, D. 2019. FishBase. (www.fishbase.org). Accessed on 01 Mar 2019.

Garcez, R.C.S.; Souza, L.A.; Frutuoso, M.E.; Freitas, C.E.C. 2017. Seasonal dynamic of Amazonian small-scale fisheries is dictated by the hydrologic pulse. Boletim do Instituto da Pesca, 43: 207-221.

Guidelli, G.M.; Isaac, A.; Takemoto, R.M.; Pavanelli, G.C. 2003. Endoparasite infracommunities of Hemisorubim platyrhynchos (Valenciennes, 1840) (Pisces: Pimelodidae) of the Baía River, upper Paraná River floodplain, Brazil: specific composition and ecological aspects. Brazilian Journal of Biology, 63: 261-268. 
Hernández-Orts, J.S.; Aznar, F.J.; Blasco-Costa, I.; García, N.A.; Víllora-Montero, M.; Crespo, E.A.; Raga, J.A.; Montero, F.E. 2013. Description, microhabitat selection and infection patterns of sealworm larvae (Pseudoterranova decipiens species complex, Nematoda: Ascaridoidea) in fishes from Patagonia, Argentina. Parasites \& Vectors, 6: 252. doi.org/10.1186/1756-3305-6-252

Jimenez, E.; Lima, D.; Amaral, M.; França, T.; Costa, M.; Souza, P.; Barbosa, C. 2017. Peixes da Zona Costeira do Parque Nacional do Cabo Orange, Estuário Amazônico, Amapá, Brasil. Printgraf, Macapá, 89p.

Leite, L.A.R.; Pelefrini, L.S.; Agostinho, B.N.; Azevedo, R.K.; Abdallah, V.D. Biodiversity of the metazoan parasites of Prochilodus lineatus (Valenciennes, 1837) (Characiformes: Prochilodontidae) in anthropized environments from the Batalha River, São Paulo State, Brazil. Biota Neotropica, 18: e20170422.

Lizama, M.A.P.; Monkolski, J.G.; Carniel, M.K.; Costa, A.P.L. 2013. Mollusca, Hirudinea, Pentastomida e Acari parasitos de peixes. In: Pavanelli, G.C.; Takemoto, R.M.; Eiras, J.C (Org.). Parasitologia de Peixes de Água Doce do Brasil. Eduem, Maringá, p.399-435.

Ludwig, J.; Reynolds, J.F. 1988. Statistical Ecology: A Primer on Methods and Computing. Wiley-Interscience, New York, 337p.

Magurran, A.E. 2004. Measuring Biological Diversity. Blackwell Science, Oxford, 266p.

McClelland, G. 2002. The trouble with sealworms (Pseudoterranova decipiens species complex, Nematoda): a review. Parasitology, 124, Suppl: S183-203.

Martorelli, S.R. 1989. Estudios parasitologicos en biotopos lenticos de la Republica Argentina. V. Desarollo del ciclo biologico monoxeno de la metacercaria progenetica de Gernachella genarchella Travassos 1928 (Digenea: Hemiuridae) parasita de Littoridina parchappei (Mollusca: Hidrobiidae). Revista del Museo Argentino de Ciencias Naturales, 14: 109-117.

Moravec F. 1998. Nematodes of freshwater fishes of the Neotropical region. Praha, Vydala Academia, $464 \mathrm{p}$.

Oliveira, M.S.B.; Gonçalves, R.A.; Ferreira, D.O.; Pinheiro, D.A.; Neves, L.R.; Dias, M.K.R.; Tavares-Dias, M. 2017. Metazoan parasite communities of wild Leporinus friderici (Characiformes: Anostomidae) from Amazon River system in Brazil. Studies on Neotropical Fauna and Environment, 52: 146-156.

Olmeda, S.A.; Mar Blanco, M.; Pérez-Sánchez, J.L.; Luzón, M.; Villarroel, M.; Gibello, A. 2011. Occurrence of the oribatid mite Trhypochthoniellus longisetus longisetus (Acari: Trhypochthoniidae) on tilapia Oreochromis niloticus. Diseases of Aquatic Organisms, 94: 77-81.

Poulin, R. 2001. Another look at the richness of helminth communities in tropical freshwater fishes. Journal of Biogeography, 28: 737-743.

Poulin, R. 2004. Parasite species richness in New Zealand fishes: a grossly underestimated component of biodiversity? Diversity and Distributions, 10: 31-37.

Rego, A.A. 1984. Proteocephalidea from Amazonian freshwater fishes: new systematic arrangement for the species described by Woodland as Anthobothrium (Tetraphyllidea). Acta Amazonica, 14: 86-94.
Rohde, K.; Hayward, C.; Heap, M. 1995. Aspects of the ecology of metazoan ectoparasites of marine fishes. International Journal for Parasitology, 25: 945-970.

Rózsa, L.; Reiczigel, J.; Majoros, G. 2000. Quantifying parasites in samples of hosts. The Journal of Parasitology, 86: 228-232.

Santos, P.H.N.; Tavares-Dias, M. 2017. First study on communities of parasites in Triportheus rotundatus, a Characidae fish from the Amazon River system (Brazil). Brazilian Journal of Veterinary Parasitology, 26: 28-33.

Silva, A.Q.; Takiyama, L.R.; Costa-Neto, S.V.; Silveira, O.F.M. 2009. Valoração ambiental das unidades fitoecológicas remanescentes da bacia hidrográfica do Igarapé Fortaleza. OLAM-Ciência \& Tecnologia, 9: 354-384.

Silva, M.C.; São Clemente, S.C.; Picanço-Júnior, J.A.; Silva, M.V.O.; Matos, E.R. 2012. Calyptospora sp. in Brachyplatystoma vaillantii trapped at the Vigia, State of Pará, Brazil. Revista Brasileira de Parasitologia Veterinária, 21: 176-178.

Soares, M.G.M.; Costa, E.L.; Siqueira-Souza, F.K.; Anjos, H.D.B.; Yamamoto, K.C.; Freitas, C.E.C. 2011. Peixes de Lagos do Médio Rio Solimões. Reggo Edições, Manaus, 160p

Taborda, N.L.; Paschoal, F.; Luque, J.L. 2016. A new species of Ergasilus (Copepoda: Ergasilidae) from Geophagus altifrons and G. argyrostictus (Perciformes: Cichlidae) in the Brazilian Amazon. Acta Parasitologica, 61: 549-555.

Takiyama, L.R.; Silva, A.Q.; Costa, W.J.P.; Nascimento, H.S. 2004. Qualidade das águas das ressacas das bacias do Igarapé da Fortaleza e do Rio Curiaú. In: Takiyama, L.R.; Silva, A.Q. (Ed.). Diagnostico das Ressacas do Estado do Amapá: Bacias do Igarapé da Fortaleza e Rio Curiaú, Macapá-AP. CPAQ/IEPA and DGEO/ SEMA, Macapá, p.81-104.

Tavares-Dias, M.; Dias-Júnior, M.B.F.; Florentino, A.C.; Silva, L.M.A.; Cunha, A. C. 2015. Distribution pattern of crustacean ectoparasites of freshwater fish from Brazil. Revista Brasileira de Parasitologia Veterinária, 24:136-147.

Thatcher VE. 2006. Amazon fish parasites. $2^{a}$ ed. Sofia: Pensoft Publishers, 508p.

Thomaz, D.O.; Costa-Neto, S.V.; Tostes, L.C.L. 2004. Inventario florístico das ressacas das bacias do Igarapé da Fortaleza e do Rio Curiaú. In: Takiyama L.R.; Silva, A.Q (Org.). Diagnostico das Ressacas do Estado do Amapá: Bacias do Igarapé da Fortaleza e Rio Curiaú, Macapá-AP. CPAQ/IEPA and DGEO/SEMA, Macapá, p.1-22

Vasconcelos, H.C.G.; Tavares-Dias, M. 2016. Host-parasite interaction between crustaceans of six fish species from the Brazilian Amazon. Acta Scientiarum. Biological Sciences, 38: 113-123.

Zar, J.H. 2010. Biostatistical Analysis. 5th ed. Prentice Hall, New Jersey, 944p.

RECEIVED: 29/03/2019

ACCEPTED: 02/10/2020

ASSOCIATE EDITOR: Linda Basson 